\title{
ISLAMIC CIVILIZATION BETWEEN MEDINA AND ATHENA
}

There were the Mahometans (Moors of Spain) who transmitted sciences to the Occident; since then, they have never wished to take benefit of what they had given us (Montesquieu [1949]: 1569).

Arnold Toynbee believes that a civilization may emerge through 1) the spontaneous mutation of a pre-civilizational society, 2) stimulation of a pre-civilizational society to develop into a civilization by the influence of an already existent civilization, or 3) disintegration of one or more civilizations of older generation and the transformation of some of their elements into a new configuration (Toynbee 1995: 85). Following this classification, Islam in its origin was a civilization of the second category. Muhammad, the Prophet of Islam, explicitly claimed being the true successor of the Abrahamian monotheist tradition in which Islam - as a religion - is but a modern and revived version of Judaism and Christianity. It is to say that even at the heart of its religion, therefore, Islam renewed itself by borrowing from ancient Eastern and Mediterranean civilizations (Braudel 1995: 73, Khamenei 1998). However, when Mohammad moved to Yathrib, an anonymous city north of Mecca, established his government, drafted a constitution and changed the name of Yathrib to Medina, it was already clear that he had greater ambitions than merely establishing a new state among others. The choice of Medina/city from which the term tamaddun/civilization is derived, was a good indicator of the real intentions of the New Apostolate. Another significant indication was the multi-ethnical character of his disciples composed of a clear majority of Arabs, but also Persians (Salman Pârsi) and Ethiopians (Balâl Habashi) were represented. Mohammad aimed at achieving a universal religion through a universal message. In Medina, Muhammad found a government with a leadership, an army, a taxation system and a new social order. The leadership was composed by a chief (Muhammad himself) surrounded by a Council of Ten (Ashara Mubashshara) representing the most powerful tribes and fractions. The crucial decisions concerning war and peace in particular were taken in consultation (mashvara) with members of the Council. The army was composed of all members of the community which at that time was quite limited. Muhammad, in the capacity of prophet and leader, was also the supreme commander of the army and participated himself in most of the battles (ghazavât). The new administration and army were mainly financed by two sources: taxation (zakât) and donation (sadaqât), and booty (qanima). The social order was based on equality (musavât) between members of the Umma/community. However, equality was rather a formal principle. A well-defined hierarchical system regulated the range and status 
of each group: the early Believers (Sahâba), which had its own hierarchical order (the Emigrants/Muhâjirûn and the Auxiliaries/Ansâr), the Believers (Mu'minûn), the Adherents (Muslimûn) and so on and so forth (Mozaffari 1987: 19-29). The entire system was cemented by a message determining the world vision of the new Community. The message, revealed by fragments, was codified under the caliphate of Othman (assassinated in 656 A.D.) and called the Koran. After the death of Muhammad, a new leadership system called Caliphate (Khalâfat), which literally means vicariate, was established. The first Caliphate, known by Muslims as the "Rightful," begun in 632 and ended in 661 A.D.

After the Formative Age, the Islamic system turned into a kingdom (mulk/saltanat), abolishing the co-optive caliphate system, replacing it by a heritage system. The great civilizations are imperial. Accordingly, the Islamic civilization also became an empire. With the Umayyads, the first Islamic Empire emerged in 661 and ended in 750 A.D. Should the creation of Umayyads be considered the beginning of an Islamic civilization? In territorial terms, there is no doubt that during the Umayyad period Islam did extend considerably; and the first pillars of a civilization were built upon. It was a clear and powerful centralized political system, based in Damascus, assisted by a new bureaucracy, recruited especially among Persians. With the Umayyads began a modeling of a new way of life and a new set of administrative, cultural and social relations. Simultaneously, the Arab grammar was structured by two Persians (Sibawayh and Zamakhshari). However, according to Fernand Braudel, "Muslim civilization began only when Islamic schools spread throughout the Umma or community of the faithful, from the Atlantic to the Pamirrs" (Braudel 1995: 73). This was the beginning of the Axial Age.

During the Axial Age, Islam became a world religion, and, as such, "it can perhaps be thought of as the first globalized world religion" (Held et al. 2000: 415). As a "globalized world religion," Islam became both integrative and dynamic. It was integrative in the sense that it easily integrated within itself not only different races, ethnicities, territories, but also and especially the cultural, philosophical and scientific baggage which the new arrivals brought along. It was dynamic in the sense that it was able to absorb the alien ideas and concepts, having enough capacity to transform them into Islamic vocabulary and express them trough Islamic terminology. From this epoch until the thirteenth century (A.D.), Islamic civilization became increasingly cosmopolitan and even secular. It was in such a way that "the creative minority - philosophers and scientists in particular - viewed religious as a conventional matrix of social norms and communal behavior" (Kraemer 1986: 14). In the time of the great philosopher and 
political scientist Al-Fârâbi (827-950), philosophers saluted the banner of religion in deference to political and social responsibility. The prevalent political philosophy, inspired by Al-Fârâbi held religious to be symbolic representations of the truth. The true and the good were determined autonomously, not on a religious background, and these criteria became the measure and standard for religion. Philosophy was viewed as independent of, not as ancillary to, faith and theology (Kraemer 1986: 15).

It was also in the same period that Islamic civilization became cosmopolitan and tolerant, where Muslims were prepared to discuss religious issues with others on a fair basis without threat of retribution (Kraemer 1986: 29). In fact, during this period, "most Arabic-writing faylasûfs/philosophers were either Christian, Jews, or Muslims; they all acknowledged the pagan Greek sages, especially Plato and Aristotle" (Hodgson 1974: 430 "I"). Kraemer attributes the open-minded character of Islamic civilization, during the Axial Age, to the emergence of an affluent and influential middle class, which, having the desire and means to acquire knowledge and social status, contributed to the cultivation and diffusion of ancient culture (Kraemer 1986: 4).

The Islamic civilization reached its zenith under the caliphate of Al-Ma'mûn (813-833) whose "intellectual curiosity was far-reaching, and his works are collections of rare and interesting knowledge concerning the human and natural world: countries, animals, the oddness of human beings" (Hourani 1991: 52). Al-Ma'mûn was the first Islamic ruler who created an official forum for free debates for intellectuals and scientists. This forum was called the "House of Wisdom"/bayt al-hikma.

Al-Ma'mûn opened his court to all kinds of intellectual tendencies, also to those philosophers and moralists whose ideas were banished by the orthodox Ulama. His personal preference was undoubtedly rationalism and especially the $M u^{\prime}$ tazili movement which at that time was the dominant school of thought in both Basra and Baghdad. There is evidence that some prominent $M u^{\prime}$ tazili figures such as Bishr Ibn alMu'tamir and Tumamam Ben Ashras had free access to the Caliph's court. Other Mu'tazilis (e.g. Bishr al-Marisi) played the role of mentor for Al-Ma'mûn. Josef Van Ess, who has studied Mu'tazilism intensely, thinks that it is very plausible that AlMa'mûn's inclination for rationalism stems from the period of his residence in Khorasan, where Hellenism was dominant from the epoch of Alexander the Great. Furthermore, it is also possible that Al-Ma' mûn created the "House of Wisdom" under Hellenistic inspiration, the Academy (Van Ess 1984: 27).

Hellenism survived a few centuries more in Islamic life, producing a group of philosophers, moralists and writers such as Al-Khârazmi (780-850), Al-Râzi (865- 
923/932), Al-Fârâbi (872-950), who tried to reconcile Hellenism with Islam, Avicenna (980-1037), and Averroës (1126-1198) who still shine in the memory of Muslims. They disappeared gradually and gave way to the dogmatics and theologians. Jurists such as Al-Ghazâli (1058-1111) and Ibn Taymiyya (1263-1328) belong to this group.

In short, this epoch was characterized by two trends. The Islamic Empire reached its peak of power, conquest, and prosperity. The Abbasid Empire represented at that time the most powerful state in the world. The second predominant trend was deep infiltration of Hellenistic ideas and cosmology which contributed to an opening of dialogue. After the end of this period, the Islamic intellectual vitality changed place, moving slowly from Baghdad, Basra, Damascus and Cairo to Southern Spain, and Andalusia, which represents the second Islamic intellectual, glorious epoch.

Andalusia evokes to Muslims a splendid epoch, intellectually and scientifically. Politically, however, the Muslim situation at that particular time was almost chaotic and full of confusion.

In political terms, Andalusia was in clear opposition to Al-Ma'mûn's epoch. At this time, the central authority in Baghdad began to weaken and faced new and serious challenges. Consequently, some relatively small dynasties began to establish themselves as autonomous or independent in different parts of the immense Abbasid Empire. One of these Empires was founded in Southern Spain by Umayyad "princes" who had escaped from the Abbasids' yoke. The Andalusian adventure, in the most positive meaning of the word, began with the Cordou Caliphate (929-1031) and continued for three centuries. This Caliphate was a successor of an Emirate which was established by the emigrants who came to North Africa and then to Southern Spain because of the Abbasid repression. During these centuries, there was great political and religious tolerance in the area. This was a necessary condition for close collaboration between the scientists of different races, religion, and political convictions. Juan Vernet's (Vernet 1978/1985) great book on La cultura hispanoàrabe en Oriente y Occidente and the two volumes edited by Salma Khadra Jayyusi (1994) entitled The Legacy of Muslim Spain perfectly describe the rise and fall of the Andulasian epoch. All disciplines of arts, music, botany, mathematics, medicine, astrology, astronomy, physics, chemistry, and many other branches were represented at that time in Andalusia. The extraordinary vitality of culture and science in this period was so great and of such variety that it is difficult to choose specific examples.

The Andalusian experience accomplished at least two main objectives: first, it created a cosmopolitan forum for different scholars of different disciplines. This extraordinary 
task could not have been accomplished without creating a hospitable environment. The result was overwhelming and greatly benefited Europe. As Margarita Lopes Gómez put it:

The flood of translations centered around the preferred fields of mathematics and science. It is to Islamic culture that we owe our knowledge of numbers, including the zero, of Indian origin but transmitted by a Muslim from Persia named AlKhwârizmî, and Muslims also developed geometry, demonstrated the position and movements of the planets and made many other scientific and medical discoveries, such as the discovery of the minor circulation of the blood, in the seventh-thirteenth century, by the Arab doctor Ibn-al-Nafîs (in Jayyusi 1994: 1060).

Second, and actually the result of the first, is the transfer of Hellenistic knowledge to medieval Europe. This transfer was undoubtedly crucial to the beginning of the Renaissance in Europe. Montesquieu affirms that "there were the Mahometans (Moors of Spain) who transmitted sciences to Occident; since then, they have never wished to take benefit of what they had given us" (Montesquieu [1949]: 1569).

The glorious epoch of rationalism and Hellenism reached its end when dogmatism and jurisprudence became dominant again in Islam. Montesquieu believes that the destruction of the Caliphate led to the destruction of sciences for Mahometans (ibid). In fact, Al-Ghazâli (1058-1111) was perhaps the first, or at least the most reputed, theologian who introduced Islam to dogmatism. Later, in the fourteenth century, Ibn Khaldun (1332-1406) tried to reintroduce rationalism in Islamic culture by founding the sociological school and his famous Prologomena (Al-Muqaddimah). Unfortunately, he was too late because the people of Islam were already in a deep crisis which finally led them to several centuries of decadence.

The Ma'mûnian and the Andalusian examples showed that the free dialogue and exchange of views and experiences were possible in two different contexts. When the central authority of the Islamic Empire was strong enough and confident - e.g. the Abbasids under Al-Ma'mûn - it could afford and neutralize any attempt at subversion. But when the central authority was disintegrated into a variety of small emirates, sultanates and caliphates in Andalusia and North Africa, the opposite was the case.

The fall of Baghdad in 1258 and the end of the Abbasid Empire by Hulâku, the grandson of Genghis Khan, also marked the beginning of further political division of the Islamic Empire. The Empire was divided among a variety of large and small emirates, sultanates, khanates, etc. 
The question now is how and under what circumstances this brilliant, cosmopolitan, tolerant, integrative and dynamic civilization declined? And when did the decline of the Islamic civilization begin? All authors agreed that Islam had created a civilization. They also agreed that the Islamic civilization reached its peak between the nineth and the second half of the tenth century (A.D.) continuing circa three centuries ahead. Fernand Braudel even specifies two dates: one for the beginning and the other for the end of the Islamic civilization. According to him, the golden age lasted from 813, the year of Al-Ma'mûn's caliphate and ended with the death of Averroës - the Cordoba physician and commentator on the works of Aristotle - in Marrakesh in 1198 (Braudel 1995: 73). In this way, Braudel rightly included the Andalusian epoch - at least partly within the golden age of Islam. Whatever the exact period of the Islamic golden age, we have to understand the causes of its decline. On this question, different responses have been provided. For the task of clarification, they should be listed as follows: 1) philosophical-intellectual; 2) geo-strategic; 3) technological-scientific; and 4) the unification of the world theory.

Philosophical-intellectual explanation. Those who are in favor of this thesis, offer two major arguments. First, there is the question of quality and intellectual aspiration of Islamic philosophy. Muslims knew very well of both Plato and Aristotle. Thus, despite the fact that Aristotelian thinking dominated their logical investigation and their reflections on ethics, their political thinking was fundamentally Platonic (Kraemer 1986: 6). Moreover, their approach to philosophy was more literal and textual than critical. The knowledge was used rather for the purpose of refinement and urbanity (adab/âdâb) than as a commitment to a specific philosophical system. Braudel attributes this fact to the force exercised by religion on philosophers. He says "as admirers of Aristotle, the Arab philosophers were forced into an interminable debate between prophetic revelation, that of the Koran, and a human philosophical explanation" (Braudel 1995: 83). Second, general stagnation of Islamic civilization was due to the spring of a powerful Islamic dogmatism in the twelfth century which aimed at eradicating philosophy as a compatible discipline with Islam as religion. This movement was led by theologians such as Al-Ghazâli ${ }^{1}$ and Ibn Taymiyya. The rise of dogmatism put an end to the tolerant, integrative, cosmopolitan and dynamic character which were the dominant trends of the golden age.

Geo-strategic explanation. Following this explanation, the decline began when power was taken over by barbarian soldier slaves (Seljuqs/Saljuks) in almost all of the Muslim territories. Parallel to this, a dramatic circumstance with long and substantial consequences ensued: after the twelfth century, Islam "lost the control of the sea" 
(Braudel 1995: 87). When Islam conquered the Mediterranean Sea by the end of the seventh century (A.D.), it was a fatal blow to the Byzantine Empire dividing the unity of the European Mare Nostrum ${ }^{2}$ and establishing, until our time even, a "barrage liquide" in Henri Pirenne's jargon. When Islam lost control of the Mediterranean, it became permanently handicapped, unable to expand and ill-equipped for the daily life (Braudel 1995: 87). The loss of the sea was not limited to the Mediterranean; in time the loss became global. Toynbee believes that the epoch rupture happened in 1498, when Frankish ships arrived in India, by Muslims considered as "water-gypsies" which could not even capture the attention of Babur, the Emperor of India. Nevertheless, the West European seafarers' voyages of discovery were an epoch-making historical event (Toynbee 1948: 62). From this moment, Islam became an exclusively territorial power deprived of the modern means of communication, which held the necessary and efficient instruments for political, economic, and cultural power.

Technological-scientific explanation. The Galileo and the Copernican revolutions fundamentally changed the human view on the world and on itself. These revolutions transformed the mentality of the population which resulted in the Renaissance and the birth of European civilization. The point is that the Islamic civilization remained untouched and uninformed. It continued its traditional way which at the time was equivalent to stagnation and further disintegration. The emerged technological rationality was characterized by three elements: 1) the progressive conquest of all areas of knowledge by mathematics; 2) the application of scientific knowledge through associated technology; and 3) the appearance of an impersonal bureaucracy (Shayegan 1997: 85). None of these elements were present in the Islamic world. Furthermore, the technological revolution demanded a secular scientific rationalism. Islam, after having experienced a dose of rationality, secularity and cosmopolitan culture during three or four centuries (ninth-thirteenth), did actually return to dogmatism and the revivification of theological sciences (figh and kalâm). ${ }^{3}$ In short, the technological backwardness of Islamic civilization at that time was enhanced by a gradual intellectual and mental backwardness. And this was the cause of its decline.

Unification of the World. This explanation is a sort of combination of various elements causing the decline of Islamic civilization. It is to say that the loss of the sea, the return to dogmatism, and technological backwardness made the Islamic civilization incapable of being dynamic and integrative. Essentially, the reason was that the sense and orientation of encounters were changed. The revolutionary Western invention was the substitution of the ocean for the steppe as the principal medium of worldcommunication (Toynbee 1948: 70). The world became unified and divided at the same 
time. Unified by the new Western system of communication, and divided by the end of encounters within non-Western civilizations. Shayegan illustrates very well the depth of the new gap. He writes:

The decline of these Asian civilizations brought their mutual cross-fertilizations to an end. The era of the great translations leading to fruitful encounters between India and China, Iran and India, China and Japan, came to an end. These great civilizations turned away from each other and towards the West. They withdraw from history, entered a phase of passivity, stopped renewing themselves and lived increasingly on their accumulated fat. They were like rich aristocratic families overtaken by events, ruined by a shift in economic reality, who keep up appearances for a time by selling off their inheritance bit by bit: jewelry, paintings, carpets, silver, everything, until the bitter day comes when there is nothing left (Shayegan 1997: 44).

The "unification of the world" did not come about through the introduction of modern communications and transportation facilities only. The most substantial change occurred in the field of economy. "For the first time in human history, an instance of a world-economy survived its "fragility" and consolidates itself as a capitalist system" (Wallerstein 1992: 223). Without going into further discussion about the rise of capitalism, it should be noted that this was a qualitative change in world history which had (and still has) a huge impact on all civilizations, including the Islamic.

Continuing its fall, the Islamic civilization completely lost the characteristic drive and will of the golden age. The decline was so striking that some authors asked whether a Muslim civilization still existed (Braudel 1995: 111). As we will see later on, the doubt about the existence of a Muslim civilization was not only Western. Muslims themselves (even the fundamentalists) asked the same question. What about the Ottoman Empire which was Islamic and survived for several centuries and was dissolved only in 1923 ? It is true that the Ottoman Empire was Islamic, but this was rather by name than by essence. In reality, the Ottoman Empire was almost a culturally inert construction contributing little to the development of Islamic civilization.

Up to this point, I have been concentrating on the explanations provided by nonMuslim authors. The reason is that as paradoxical as it may appear, there were not many Muslim thinkers (except for Ibn Khaldun) who, in the medieval period, which is concurrent with the beginning of the Islamic decline, were interested in the study of the decline of Islamic civilization. In fact, Muslim consciousness about their own stagnation and fall only arose after the Napoleonic invasion of Egypt in 1798. During 
the French occupation of Egypt, the Muslims became aware of their own backwardness in social, political, technological and intellectual terms. Thanks to Al-Jabarti who with an extraordinary precision and accuracy described this encounter (Al-Jabarti 1995). This event had a tremendous repercussion on Muslim awareness starting in the nineteenth century and continuing in the twenty-first. Thinkers and leaders such as AlAfghani (1839-1897), Muhammad Abduh (1849-1905), Al-Tahtawi (1801-1873) and many others tried to reform Islam and the Muslim way of life by observing the progress of Europe. The important thing is that from this period all Muslims admitted the decline of Islam in terms of civilization and the necessity for reform. As described by a Muslim leading thinker of the twentieth century:

During the last century, we became aware that we - Muslims - need a deep rooted and correct reform in our religious approach. We need to revive Islam by returning to the limpid source from which we have been lost during fourteen centuries [author's translation] (Shariati 1973: 2-3).

This citation illustrates a genuine Muslim discourse capturing the essence of all discourses (reformist and fundamentalist under their different etiquette) from the past century until the present time. The genuine discourse attests the progress of the Western world and the backwardness of the Islamic; although two incontestable facts, the solution proposed is not the logical result or consequence of the observed facts. Instead of looking forward, trying to combine the idea and the path of progress, it proposes regression and looks backward by rhetorical statements such as "returning to the limpid source from which we have been lost during fourteen centuries." Muhammad Khatami also acknowledged the non-existence of an Islamic civilization in our time. He made a useful and correct distinction between Islam as a religion and Islam as a civilization. He wrote: "if the sun of Islamic civilization...declined and its time passed; this was [only] the end of a [specific] interpretation of Islam, and not the end of religion" (Khatami 1997:183).

In short, all Muslims acknowledged the decline of the Islamic civilization. They have interiorized this fact at the same time as they are avoiding to draw the necessary conclusion in accordance with the already observed and accepted fact.

While Muslims agree on the decline of Islamic civilization, they are significantly divided on the ways of reconstructing it. Is reconstruction possible? Is there any empirical evidence? Reconstruction differs from reproduction in the sense that the former does not aim at reproducing something identical to something else. On the contrary, reproduction is, in a way, aiming for reincarnation. One thing is a 
photography, another is a painting. Reproduction is mechanic and reconstruction intellectual. The process of reconstruction takes place at two stages: first "civilization" which is subjected to revision and renewal must be deconstructed. Without deconstruction, the concept of "civilization" will remain vague and a-historic. The proposed deconstruction model is based on a specification of the elements of a civilization, which, in a condensed form, is composed by two elements: a world vision and a historical formation. Subsequent to this acknowledgement, follows the second phase: the reconstruction stage. As we know, civilizations are generally long-lived extending over many centuries. When talking about the reconstruction of a specific civilization, we do not mean that the target civilization must be reconstructed in its entire life. We have a selected momentum, as well as certain values, ideas, concepts, organizing principles etc.; all of which relate to this specific civilization. By reconstruction, I mean that a civilization is a great civilization only when the world vision and the historical formation meet in a coherent and fertile manner. Thus, the Islamic civilization, which is our case of study, does not necessarily exist for fourteen centuries; probably just for three or four centuries where the above mentioned elements constitute one integrated system. The advantage of such a method stems from its empirical verifiability since we know when and in which specific periods the junction occurred. In this connection, the best and perhaps most unique example for a successful reconstruction of a declined civilization is the Renaissance. The Renaissance was a reconstruction of the Greek and Roman heritage all together. Athens represented the main source of inspiration, the "idea" and the "spirit" while Rome stood for the "body," a form of organizing power based on law and prosperity. Apart from these two basic elements from which sprang the European civilization, Christianity added itself to it as an ad hoc element; subsequently the rising capitalism completed the construction. The Renaissance model exemplifies the course and the mechanism to apply for a successful reconstruction.

Following the above discussion, we have to investigate the possibilities, opportunities, and the Muslim view on the subject.

\section{Three Main Currents}

Different authors have presented different classifications of Muslim tendencies towards the revival of Islam. In this connection, Fred Halliday identified four distinct responses or themes from within an Islamic discourse. 
The approaches they adopt are classifiable as: assimilation, appropriation, particularism, confrontation; to which may be added a fifth approach, present within Islamic societies and the non-Muslim world and falling outside an Islamic discourse. This fifth could be described as the incompatibility thesis (Halliday 1995: 135-36).

Toynbee, already in 1948, long before the rise of the Islamic fundamentalism and Islamic revolution in Iran, made a broader and, in a sense, a prophetic classification of Muslims by dividing them into Zealots ${ }^{4}$ and Herodians. ${ }^{5}$ Muslim leading figures have their own classification. Personalities such as Sayyed Qub (executed in 1966), AlMawdudi (d. 1979), Shariati (d. 1977), Khomeini (d. 1989), Soroush, ${ }^{6}$ and Khatami have almost the same classification. They divide Muslims into three categories: the Traditionalist-Conservatives, the True-Revolutionaries, and the Corrupt (e.g. the Shah of Iran, President Sadat of Egypt, and the Saudi royal family). Each of these groups of course holds different views on the revival problematic. In this study, for the purpose of a better clarification, I divide Muslim options adopted vis-à-vis the renewal of Islam into three paths or three main currents: ${ }^{7}$ reproductivism, communalism and universalism.

\section{Reproductivism}

Reproductivism is animated by an idé-fixe and is an attempt at reincarnating an ossified body. What must be reincarnated is the Medina model at the time of Mohammad (Madinat $u l-N a b \hat{i})$, and to some extent the period succeeding the death of Mohammad (632 A.D.), the epoch of the Rightful Caliphs (632-661). This approach has at least the advantage of clarity and accuracy. It refers to a specific time, space within which an explicit world vision did create a historical formation. All these elements are empirically verifiable. The time is limited to 622 until 632 or 661 . The space is geographically located in Medina, and secondarily in other parts of the Arabian Peninsula. The world vision is represented by the message embodied in the Koran and, the historical formation is illustrated by the government of Mohammad and his four immediate successors. The Medina with its fixed set of values (unchanged forever) is perceived as the perfect city, the sublime form of human organization and the unique valid model for humankind. What is important to know is that the Medina model is not considered the point of departure or a source of aspiration in itself. It is, indeed, the arrival and the final point; the harbor, not the voyage. Consequently, the task of Muslims, today as at any time in history, consists in recreating the Medina model as close as possible to the original version. Leaders and thinkers such as Khomeini, Sayyed Qutb, Mawdudi and many others who share this view do not, however, reject science and technology. In this 
respect, it is interesting to observe how Ayatollah Khomeini admits new technology and his opinion on Western civilization. In his Political Testament, he writes:

If civilization means innovations, inventions and advanced technology, neither Islam nor any other monist religion opposes. But if civilization and modernization (tajaddud) implies - as the professional intellectuals put it - freedom in all illicit (prostitution, even homosexuality) and other such things, these things are in contradiction with all religions since they are in contradiction with scientists and rationalists (Khomeini 1990: 178) [author's translation].

Mawdudi, another reproductivist, explains the reason why Muslims - without concern - may apply the modern science. It is because "the modern science was not based on any particular philosophical perspective, nor did it promote a set of values or require an attitude from Muslims that could interfere with their faith" (quoted by Nasr, 1996: 53). As for what they accept, there are some techniques which "can be exchanged and diffused fairly easily in isolation." As for what they reject, there is "a certain scientific vision of the world in conjunction with a certain perception of reality"; they reject any new set of values, any thought which could disturb the koranic immutable set of values. ${ }^{8}$ Hasan al-Turâbi, the influential Sudanese Islamic fundamentalist leader, represents another example of this tendency. In his point of view, revival was required by the need for a "total revival in all aspects." Revival here is not to be understood as modernization along Western lines. Revival is seen as a means toward the establishment of a new society where shari'a is applied. Furthermore, Turâbi, in our days, claims what Al-Ghazâli claimed in the eleventh-twelfth centuries (A.D.): renewing the fundamentals of religion (Abu Khalil 1995: 435). Turâbi's arguing is circular indeed: we have to revive Islam, in all aspects with the purpose of returning to shari'a. The claimed values here are static, because the reproductivists do not recognize the autonomy and authority of the human being. On this question, a scholar, criticizing the fundamentalist approach, writes that man "is everything because he is the jewel of creation, distinct from the other created beings in that he incarnates the divine Logos; but he is nothing, because he is not a founding authority" (Shayegan 1997: 34). Another important characteristic of this approach stems from their belief in the absolute supremacy of Islamic civilization over all others in the past as well as in the future. In fact, they believe in the existence of a single civilization: the Islamic. All others are either thought of as corrupt or unjust and considered jâhiliyya/ignorant. Consequently, in the contemporary world where the Western civilization is dominant, Muslims must opt for an antagonistic attitude vis-à-vis the West as did Muslims in the formative period of Islam towards Persian, Byzantine, and other civilizations and empires. They 
could also "wait for the West to destroy itself and then take the place of the West in the world leadership." This confrontation mentality is ignoring the reality that "if the West destroys itself, either physically or morally, it will hardly perish alone" (Hodgson 1974: 430 “III").

\section{Communalism}

Communalism refers to a group of individual Muslim thinkers who have not yet formulated a coherent discourse; thus they are all aware of the weakness and inaccuracy of the reproduction theses and try to conciliate certain aspects of Islam with certain aspects of modernity. They may be called half and half: half zealot and half herodian; half traditionalist and half modernist; half democrat and half theocrat. Their main reference model remains Medina;" "the limpid source," however, not as an immutable model, nor in order to return and stay in the past - which is pure regression - but rather to discover the essence of Muslim identity and its refinement in the mentalities and habits as well as to achieve a rational criticism of the past in order to find the proper support for today...to reach a future more grand than the past.

They distinguish between religion and ideology, arguing also for a further distinction between society and Islam which is eternal and unchanging on the one side and, the "human understanding of Islam" which is changing on the other (Shariati and Soroush). They believe in a religious society hence rendering the government religious; a such society remains open by permitting criticism and where nobody is above criticism.

The above view was shared by e.g. Afghani (d. 1897) and Abduh (d. 1905) in the nineteenth century and, by Shariati, Bazargan, ${ }^{10}$ Arkoun, ${ }^{11}$ Hassan Hanafi, ${ }^{12}$ Soroush and Khatami in the twentieth to the twenty-first century. In their point of view, Medina remains the original source, thus not as an immutable one. They advocate a new interpretation of Islam in which "reason" must play a key role. In a sense, they represent the New Mu'tazila of Islam. Some of them (e.g. Arkoun, Hanafi, Bazargan) are more rationalist than others. Apparently, their favored historical reference to Islamic civilization is essentially Al-Ma'mûn's epoch where Islam was tolerant, rational, cosmopolitan, and powerful. This group is fully aware of the decline of the Islamic civilization, but they believe that a new one can/must be reconstructed. Assuming it is true that the glory (historical formation) of Islam belongs to the past, the religion (world vision) is still alive in their view, and "religion is broader than a single civilization." They accept "the positive aspects of Western civilization rejecting only the Western vision on freedom and on the human being which is wrong, narrow and 
unidimensional" (Khatami 1997: 183-191) [author's translation]. The fact that they do not reject in toto Western civilization as does the Reproductionists, and that they pay respect to "reason," indicates that implicitly they accept the multiplicity of civilizations. It is in this spirit that the Organization of the Islamic Conference (OIC) embracing all Muslim countries chaired (1997-2000) by Iran, launched the idea of organizing a "world dialogue among civilizations." On 4 November 1998, the UN General Assembly proclaimed the year 2001 as the UN Year of dialogue among civilizations. This resolution was initially proposed by President Khatami of Iran. Such initiatives from these quarters are positive, and also appear to be the appropriate solution for a reconstruction of Islamic civilization. The problem lies in the ambivalence and the contradictory character of this type of reconstructive project. It is not clear which part of the past is likely to be included in the reconstructed civilization and, which part will be rejected. Along the same lines, how much of Western civilization is likely to be integrated into the "New Islamic Civilization?" Will the partial integration of the Western civilization be limited to the technological rationality, or will it also comprise scientific mentality, critical spirit, the idea of freedom and human rights? How to combine individual freedom with a religious government? Democracy, theocracy or theo-democracy? How can a monotheistic conscience, which evolved in an agrarian context, and a pre da-Gama world vision possibly be transformed into a modern, prosperous and powerful civilization? The most significant element of the Islamic heritage now is religion and religious conscience. Is it possible or likely to create - in our time - a new civilization on the basis of the same religion or on religion in general? These questions need answers, or at least to be offered the clarification which is still lacking in communalism. It should be noted, however, that some of the communalist thinkers (e.g. Khatami) does provide clarifications; these clarifications consist in the rejection of principles such as "freedom" which constitute the pillar of Western civilization. Therefore, to claim that they represent the communitarian thesis is not an exaggeration. In the best case, this will lead to a neoShar'î communalist revival.

\section{Universalism}

From this point of view, the reconstruction of a declined civilization is directly conditioned by the world-time where the new civilization will emerge. In the old world, living civilizations interacted. In that world, a particular civilization could be renewed itself having gone through a process of weakness and decay. One reason for the existence of a such possibility was that the cumulative process consisting of perpetual learning and accumulating experiences proceeded almost internally, within the 
civilization's own universe. This situation enabled various civilizations to live in separate spaces, side by side, at the same time. In our time, under the pressure of the world system represented essentially by what Braudel called the world economy, and combined with a progressive tendency towards globalization, the very existence of different civilizations - each preserving their own set of values, world vision, ethics and political organizing principle, and operating with their own parochial economic system (world economy) is hardly plausible. How can different civilizations continue to live together in a world governed by global capitalism and by increasingly standardized civilization and human rights? In such a world, different cultures can easily live together and mutually enrich. However, civilization in my definition can hardly be more than one. Furthermore, if we recognize that "the need, even the urgency, for "universal references" has never been so strong as in our time" (Bourricauld 1987: 21) we have no other alternative than to admit the existence of such "references." Where should we search for "universal references" today? Some may suggest the internet. Actually, this is not a bad guess. But, more seriously, it seems obvious that the majority of these references are to be found in the Western civilization. Here, we have to distinguish Western civilization from Westernization. These two concepts have often been confused, hence creating further confusion, misunderstanding, and an opportunity to exercise manipulation of the people and to justify the authoritarian political regimes in Muslim countries. The distinction consists in the former concept referring to a set of values and concepts embodied in a world vision which is materialized in a specific historical formation generally referred to as Western civilization. Ideas such as belief in progress, freedom of speech and mind, equality, justice, democracy, and secularity are representative basic concepts of this civilization. Having said this, the objectionable side of the West expressed by colonialism, domination, exploitation, and war should not be ignored. The point is that the objectionable side is not the whole story of the West, and to reduce the West only to its non-civilized side would be incorrect. Furthermore, these elements are far from being specifically Western; all other empires and civilizations have been expansionist, conducting war and committing crimes against humanity, including a succession of Islamic empires (e.g. the Umayyad, the Abbasid, and the Ottoman Empires). However, none of those were based on the trilogy liberté, égalité, fraternité or on other related ideas. In addition, none of those created an economic system (capitalism) which is applicable world wide for good and for bad. The "Westernization" is a mimetic and mechanical adoption of some superficial and trivial aspects of the way of life in Western societies. Doing the things in a way that has no relation with the quality or state of being real. To allow import of goods with the sole purpose of emphasizing the consumer's distance from their indigenous 
environment. This is a kind of alienation, a "plague."13 This is one of the main reasons why, in Muslim societies, the West is often perceived as trivial, morally decadent, luxurious, dominant, arrogant all together, at the same time. In this imaginary world, Westerners are caricatured as a bunch of immoral exploiters who, by stealing Muslim natural resources, do not have to work and may spend their time drinking alcohol and practicing free and bizarre sex.

Faced to the "Westernization," the Muslim universalists deny this reductionist and superficial picture of Western civilization. They do not consider Western civilization as a civilization belonging only to the West. As Toynbee puts it: "The West is not just the West's own parochial concern but is their past history too" (Toynbee 1948: 83). A West the basic set of values of which - if not universal - are certainly universalisable (Morin 1987); although a civilization with the potential of being "universal." The reason is that its basic set of values is broader than those of all other existing civilizations taken separately.

The reconstruction project of Muslim universalists consists in: 1) considering the existing Western civilization as the necessary basis for a universal civilization; 2) qualitative transformation of Muslims to actors and contributors to universality, instead of challenging it and being ultimately submitted to it; 3) preserving cultural and Muslim identities. How can this be concretized. The first step consists of "mental migration" from a parochial and communitarian orthodox mentality to a forward looking mentality by joining a broader value system with gender equality, religious equality, freedom of speech and mind, social justice etc.; leaving also aside a permanent suspicion towards the West concerning an illusionary mysterious international plot against Islam and Muslims. This purely imaginary perception results in needless frustration causing unproductive cultural and political depression. As already mentioned, in the globalizing process that the world is currently experiencing not only Islam is challenged; globalization challenges every religion, ideology, culture, including those of the West.

Along these lines, we have to recognize that Islam represents a high culture. Islam poses a message to humanity. The concept of Umma/community, the Islamic notion of brotherhood, recognition of differences between people, principles concerning human moral and physical integrity are among many others which could be transmitted to the universal civilization. However, a reinterpretation of these concepts is called for. Umma is easily "universalisable." In a period of globalization where people are becoming citizens of the global village, sharing the same destiny, facing similar problems 
(environment, health, internet, $\mathrm{CNN}$, disaster, etc.), they are in reality members of the same community: the Umma. Thus, the Umma of Islam (Ummat al-Islâmiyya) may be extended to the Umma of humankind (Ummat al-Insâniyya). Another fact is that Islam is alien to racism, preaching universality and equality among human beings. In reality, these elements constitute powerful pillars of Islam's strength, and are highly qualified to contribute largely to the improvement of "Western" civilization. Furthermore, Islam's particular focus on justice/'adâla could bring new blood to a civilization suffering from lack of justice. The virtue of compassion/sabr and the quality of solidarity/ta'âwûn are necessary for an improvement of the dominant capitalist system. There is quite a long list of components which Islam may contribute with. Other elements must be set aside for use in the reconstruction task. Considering the world power system today, it is undeniable that

something of the leadership ...for all mankind is likely to come from the West. But moral vision cannot be left to the West alone. Muslims must face their share of the tasks. There is much in their heritage itself that should help them find the relevance of that heritage to Modern mankind (Hodgson 1974: 436 "III").

What is also necessary is a "heroic act, maybe; Promethean audacity, perhaps; rebellion against established truths, undoubtedly" (Shayegan 1997: 34). The problem is that these "Herodians," who are called to audacity and rebellion, are absolute minorities in Muslim societies. Muslim thinkers and intellectuals who firmly believe in a universal civilization, with Islamic contribution and participation, are generally quite reluctant to express their ideas explicitly. Maybe to avoid reactions (sometimes violent); they are also liable to allegations labeling them as "Western agents." In general, they try to attract public attention to their ideas through the translation of classical works of thinkers such as John Locke, Jean-Jacques Rousseau, Voltaire, Hobbs and contemporary authors such as Karl Popper, Bertrand Russel, and Jürgen Habermas. Nevertheless, taking the current situation in Iran as example, it is astonishing that, in recent times, some groups of especially young men and women slowly emerged from the very heart of a fundamentalist culture and regime. One of them, among the most active and open-minded, is composed of people who joined forces around the newspaper Jâmi'a (Society). In the issue of 1 July 1998, one could read the following lines:

In the matter of History and Civilization, we [Muslims, Iranians?] are plying the role of radical critics. Criticizing [Western civilization] is, of course, much easier than participating in its improvement" [author's translation]. 
In a democratic-pluralist society, such a statement sounds normal, maybe too normal, even a commonplace remark. But considering that it was published in today's Tehran, where Western civilization is still perceived as "satanic," the statement takes a different dimension.

On 27 July 1998, Jâmi'a ceased its publication in accordance with an order from a jurisdictional trial.

\section{Conclusion: Islam and the New Hellenism}

Islam created a great civilization. This civilization is no longer alive. What we have today are agglomerations of Muslim people organized within a variety of states. Others live in states (e.g. India, Russia, USA, and European countries) which are not Muslim. The Muslim world is not the only one to be challenged by globalization. Globalization challenges every civilization, every ideology, and every society. In addition, what complicates the process of connecting Islam to the modern and globalizing world must essentially be found in the special character of MuslimEuropean relations. While there was no noticeable religious war between European Christianity and other religions (Judaism, Buddhism, Hinduism, Confucianism, etc.), there were bloody, religious wars between Islam and European Christianity (e.g. the Crusades). Furthermore, while there were no genuine wars (of non-religious character) between European powers and non-European powers within Europe, there were multiple wars between Muslim and European powers. In Poitiers (732), in Constantinople (1453), in Grenada (1492), in Vienna (1529 and 1683), etc. This means that during history, Muslims and Europeans have been in direct physical contact within Europe. Therefore, from a European point of view, Islam represents a unique case. And Muslims have a different perception of Europe and the West compared to other colonized and dominated people (Chinese, Hindu, Indians, etc.). Those people were colonized by Europe but they were physically remote. In contrast, some Muslims were in a sense Europeans (e.g. the Umayyads in Spain and the Ottomans in large parts of Europe). The historical factor alone does not sufficiently explain the entire problematic of Islam and Globalization; it explains however an important part. Other parts are common as well for Muslims as for other colonized and dominated people of the world.

Many Muslims dream of a revival of Islam. This dream took flight once they discovered and acknowledged the decline of the Islamic civilization. Since the nineteenth century, the Muslim dream has taken different shapes and proportions. The real struggle is going on between those who believe that a reconstruction of Islamic 
civilization can only be realized through new patterns. In contrast to this view, there are those who struggle (sometimes violently) for ideas and projects which call for a reproduction of the original model. The idea of modernity is rejected, and some Muslim utopians even advocate the creation of an Islamic global world. However, the success of a reconstruction depends - in the first place on the extent to which it is connected with reality; i.e. the present time. An overwhelming number of facts and reasons indicate that the world is moving towards a broader construction rather than a pure narrow religious construction. The trend of neo-religious communities are, in fact, reactions to universality, or at least to globalization, rather than being independent factors. I argued that Islam as a civilization is unlikely to be reproduced. At the same time, I argued that Islam holds a valuable set of values and visions which are highly likely to be incorporated into the new world system. The notion of Umma, 'Adâla, even 'Asabiyya are needed for the improvement of Civilization. Robert Cox provides us with a redefinition of 'Asabiyya by putting it in a world system context. 'Asabiyya as a supra-intersubjectivity, a new "global Mahdi"/saviour which could take the form of a collectivity rather than an individual. This "supra-intersubjectivity would have to embody principles of coexistence without necessarily reconciling differences in goals. It would have to allow for a degree of harmonization of trajectories of different macro-societies" (Cox 1996: 168).

Twice, Islam has missed the opportunity of conciliation with Hellenism: the first time due to a massive dogmatic influence during the twelfth-thirteenth centuries, and the second time, with the end of the brilliant Andalusian experience; a sort of "Islamic Silicon Valley." For some Muslims, globalization, especially in its intellectual significance, represents a New Hellenism. From this point of view, Muslims must not miss this new opportunity. They have to proceed to achieve a religious reformation. This would pave the way to modernity, democracy and intellectual liberalism. For others, the Medina remains - forever - the true and valid model. Along these lines, "salvation" will be realized only by a return to the Medina model. The outcome of the inter-Muslim struggle will ultimately determine the Muslim response to globalization.

\section{Notes}

${ }^{1}$ On Gazâli, see particularly Henri Laoust, La Politique de Ghazâli, 1970.

${ }^{2}$ In a sense, this event did contribute to the rise of European civilization which will progressively dominate the world. As Henri Pirenne puts it: "L'Occident est embouteillé et forcé de vivre sur lui-même, en vase clos. Pour la première fois depuis toujours, l'axe de la vie historique est repoussé de la Méditerranée vers le Nord. La décadence où tombe à la suite de cela le royaume mérovingien fait apparaître une nouvelle dynastie, originaire des régions germaniques du nord, la Carolingienne" (Pirenne 1937: 187). 
${ }^{3}$ It is astonishing that Al-Ghazâli, the most prominent figure of dogmatism, named his monumental work "Revivification/Ihyâ" which is a clear indication of the dominant trend of his time. In fact, the revivification was a dogmatic renaissance; a rupture with philosophy and Hellenism and a return to theology.

4 "The 'Zealot' is a man who takes refuge from the unknown in the familiar, and when he joins battle with a stranger who practises superior tactics and employs formidable newfangled weapons, and finds himself getting the worst of the encounter, he responds by practising his own traditional art of war with abnormally scrupulous exactitude" (Toynbee 1948: 188). The North African Sanusis and the Central Arabian Wahhabis (Saudi Arabia) are used as examples.

5 “The 'Herodian' is a man who acts on the principle that the most effective way to guard against the danger of the unknown is to master its secret; and, when he finds himself in the predicament of being confronted by a more highly skilled and better armed opponent, he responds by discarding his traditional art of war and learning to fight his enemy with the enemy's own tactics and own weapons"(Toynbee, 1948: 193-94). As an example of a Herodian, he mentions Mustafa Atatürk.

${ }^{6}$ Abdulkarim Soroush (alias Hossein Dabbagh) studied pharmacology in Iran and history and philosophy of science in England. After the Revolution of 1979, he became one of the most influential ideologists of the Islamic revolution and was a member of the Committee of the Cultural Revolution until 1987 where he resigned. Soroush is the author of many books and articles such as), Theoretical Contraction and Expansion of the Shari'a, (1991/1996) (in Persian) and Reason, Freedom, and Democracy in Islam, 2000. For a short review of his ideas, see Valla Vakili (1996).

7 "Muslims" here are both the Muslim believers and those who were merely cultural or secular Muslims.

${ }^{8}$ On this point, Mawdudi declares that "We aspire for an Islamic renaissance on the basis of the Qur' an. To use the Qur' anic spirit and Islamic tenets are immutable, but the application of this spirit in the realm of practical life must always vary with the change of conditions and increase of knowledge" (quoted in Nasr, 1996: 51).

${ }^{9}$ Khatami's statement on Medina is insightful. He says that "The civil society we have in mind has its origin from a historical and theoretical point of view, in Madinat ul-Nabî" which "remains our eternal moral abode" (Khatami 1997b).

${ }^{10}$ Mehdi Bazargan was a French educated engineer who became Professor at Tehran University and the leader of the Liberation movement of Iran. After the Islamic revolution in Iran in 1979, he became the first Prime Minister of the revolutionary regime, but resigned November 1979 after the occupation of the US embassy in Tehran and the 'hostage affair'. He is the author of a number of books and articles through which he tried to reconcile Islam with modern science. He died in 1995.

${ }^{11}$ Mohammed Arkoun was Professor at Sorbonne in Paris and is the author of books on Islam. Among his best work is Pour une Critique de la Raison islamique, Paris, Maisonneuve \& Larose, 1984.

${ }^{12}$ Hassan Hanafi is Professor at Cairo University and one of the front figures of the Islamic revivalists. One of his works is Istighrâb/Occidentalism (in Arabic) which is a reply to Orientalism. See also his article on "An Islamic Approach to Multilateralism,"1997.

${ }^{13}$ Jalla Al-e Ahmad, an Iranian author whose writings have had a decisive influence on the decline of the Shah's regime described - not without exaggeration - the impact of 
westernization on the Iranian society. See his book on Plagued by the West/Gharbzadegi, 1982.

\section{References}

Abu Khalil, As'ad (1995), "Revival and Renewal", in John L. Esposito, The Oxford Encyclopedia of the Modern Islamic World, vol. 3.

Al-e Ahmad, Jalla (1982), Plagued by the West, trans. by Paul Sprachman, New York, Caravan Books.

Arkoun, Mohammed (1984), Pour une Critique de la Raison islamique, Paris, Maisonneuve \& Larose.

Bourricauld, François (1987), "Modernity, Universal References and the Process of Modernization" in S.N. Eisenstadt (ed.), Patterns of Modernity, vol. I, New York, New York University Press.

Braudel, Fernand (1995), A History of Civilizations, USA, Penguin Books.

Cox, Robert W. with Sinclair, Timothy J. (1996), Approaches to World Order, Cambridge, Cambridge University Press.

Halliday, Fred (1995), Islam \& the Myth of Confrontation, London, I.B. Tauris.

Hanafi, Hassan (1991), 'Ilm ul- Istighrâb [Occidentalism], Cairo, Dâr ul-Fanniyyah, (in Arabic).

Hanafi, Hassan (1997), "An Islamic Approach to Multilateralism", in Robert Cox (ed.), The New Realism, Tokyo, Macmillan.

Held, David, et al. (2000), Global Transformation, Cambridge, Polity.

Hodgson, Marshall G.S. (1974), The Venture of Islam, Chicago, The University of Chicago Press, (I, II and III).

Hourani, Albert (1991), A History of the Arab Peoples, London, Faber \& Faber.

Ibn Khaldun, Abdelrahman (1968), The Muqaddimah, trans. by Franz Rosenthal, 3 vols, London, Routledge \& Kegan Paul.

Jayyusi, Salma Khadra (ed.) (1994), The Legacy of Muslim Spain, Leiden, E.J. Brill.

Khamenei, Sayyed Ali (Supreme Leader of Iran) (1998), "Today, the World Needs the True Islam", in Ettela'at, 9 July (in Persian).

Khatami, Sayyed Mohammad (1997), Bîm-é Mowj [Fear of the Wave], Tehran, Simây-e Javân, (in Persian).

Khatami, Sayyed Mohammad (1997b), "Statement to the 8th Session of the Islamic Summit Conference," Tehran, 9 December.

Khomeini, Ayatollah (1990), "Political Testament", in Sahifay-e Nur [Light's Scriptures], Tehran, Soroush, (in Persian).

Kraemer, Joel L. (1986), Humanism in the Renaissance of Islam, Leiden, E.J. Brill.

Laoust, Henri (1970), La Politique de Ghazali, Paris, Paul Gauthner.

Montesquieu, Charles-Louis de [1949] (1569), "Considérations sur les causes de la grandeur des Romains et de leur décadence" in Oeuvres Complètes (II), Paris, Gallimard.

Mozaffari, Mehdi (1987), Authority in Islam: From Muhammad to Khomeini, New York, M.E. Sharpe.

Nasr, Seyyed Vali Reza (1996), Mawardi and the making of Islamic revivalism, New York, Oxford University Press.

Pirenne, Henri (1937/1961), Mahomet et Charlemagne, Paris, Club du Meilleur Livre. 
Shariati, Ali (1352/1973), Tamaddun va Tajaddud/Civilization and Modernization, Speech (10 Dey 1352/31 December 1973).

Shayegan, Dariush (1997), Cultural Schizophrenia: Islamic Societies Confronting the West, Syracuse University Press.

Soroush, Abdulkarim (1991/1996), Qabz wa Bast-e Teoritik-e Shari'at [Theoretical Contraction and Expansion of the Shari'a], Tehran, Sarat, (in Persian).

Soroush, Abdulkarim (2000), Reason, Freedom, and Democracy in Islam, trans. by Mahmoud and Ahmad Sadri, Oxford, Oxford University Press.

Toynbee, Arnold (1948), Civilization on Trial, New York, Oxford University Press.

Toynbee, Arnold (1995), A Study of History, London, Oxford University Press.

Vakili, Valla (1996), Debating Religion and Politics in Iran: The Political Thought of Abdulkarim Soroush, New York, Council of Foreign Relations.

Van Ess, Joseph (1984), Une lecture à rebours de l'histoire du Mu'tazilism, Paris, Geutner.

Vernet, Juan (1978/1985), Ce que la culture doit aux Arabes d'Espagne [original title: La Cultura hispanoárabe en Oriente y Occidente], Paris, Sindbad.

Wallerstein, Immanuel (1992), Geopolitics and Geoculture, Cambridge, Cambridge University Press. 